\title{
Value Of Religiusity In The Mujahadah Tradition; Study at Ulul Albab Nganjuk Islamic Vocational School

\author{
Hilma Dian Wulandari ${ }^{1}$, A. Jauhar Fuad ${ }^{2}$ \\ ${ }^{1}$ Institut Agama Islam Tribakti Kediri ${ }^{2}$ Institut Agama Islam Tribakti Kediri \\ ${ }^{1}$ hilmafitriana22@gmail.com, ${ }^{2}$ info.ajauharfuad@gmail.com
}

\begin{abstract}
This paper aims to examine the values of religiosity through the mujahadah tradition at Islamic Vocational School Ulul Albab Nganjuk. This research departs from two research questions, "How is the mujahadah tradition in Ulul Albab Nganjuk Islamic Vocational School? What are the religious values contained in the mujahadah tradition at SMK Islam Ulul Albab Nganjuk?". This research is a qualitative research with a phenomenological approach. This research conducted in Ulul Albab Islamic Vocational School. Data collection techniques using in-depth interviews and partisipan observation. With these two questions, the results of the study found that (1) the mujahadah tradition is a behavior to fight lust, as an effort to combat all bad attitudes caused by lust of anger. Meanwhile, the mujahadah tradition at Ulul Albab Islamic Vocational School contains the recitation of Hizbul Quran and Rotib Hadad, then continued with sunnah prayers, reading rotib istigasah then tausiyah after that it is continued with dhuhur prayer in congregation and ends with mushofahah. (2) Mujahadah which is held at Ulul Albab Islamic Vocational School is intended so that all students can become better individuals and so that their spiritual souls can increase, and also so that their spirituality will mature. The results of observations on the implementation of the mujahadah at Ulul Albab Islamic Vocational School show that students' awareness of the importance of the mujahada is still lacking, but in its implementation they are very enthusiastic and happy in doing it, although the changes seen are still not optimal.
\end{abstract}

\section{Key Word: Mujahadah Tradition, Religiosity Value}

\section{Abstrak}

Tulisan ini bertujuan untuk mengkaji nilai-nilai religiusitas melalui tradisi mujahadah di SMK Islam Ulul Albab Nganjuk. Penelitian ini berangkat dari dua pertanyaan penelitian, "Bagaimana tradisi mujahadah yang ada di SMK Islam Ulul Albab Nganjuk? Apa nilai-nilai religius yang terkandung dalam tradisi mujahadah di SMK Islam Ulul Albab Nganjuk?" Penelitian ini merupakan penelitian kualitatif dengan pendekatan fenomenologi. Penelitian ini dilakukan di SMK Islam Ulul Albab Nganjuk. Teknik pengumpulan data menggunakan wawancara mendalam dan observasi partisipan. Dengan dua pertanyaan di atas, hasil penelitian menemukan bahwa (1) Tradisi mujahadah merupakan suatu perilaku untuk melawan hawa nafsu , sebagai bentuk usaha untuk memerangi segala sikap buruk yang ditimbulkan oleh nafsu amarah. Sedangkan Tradisi mujahadah ini di SMK Islam Ulul Albab ini berisi tentang pembacaan Hizb al-Quran dan Ratib Hadad, kemudian dilanjut dengan salatsalat sunnah, pembacaan ratib istigasah kemudian tausiah setelah itu dilanjut dengan salat dhuhur berjamaah dan diakhiri dengan mushafahah. (2) Mujahadah yang 
dilaksanakan di SMK Islam Ulul Albab ini bertujuan agar seluruh siswa-siswi dapat menjadi pribadi yang lebih baik lagi dan supaya jiwa spiritual mereka bertambah, dan juga ruhaniyah mereka bertambah matang. Hasil observasi pada pelaksanaan mujahadah di SMK Islam Ulul Albab ini menunjukkan bahwa kesadaran siswa akan pentingnya mujahadah masih cenderung kurang, namun dalam pelaksanaannya mereka sangat antusias dan senang menjalankannya, meskipun perubahan yang terlihat masih belum maksimal.

Kata Kunci: Nilai Religiusitas, Tradisi Mujahadah

\section{Introduction}

The mujahadah tradition is inseparable from an existing practice (such as dhikir and istigasah) and has been around for a long time and was carried out by our predecessors, such as masyayikh or religious leaders and warriors as a form of riyadhah, to train one's personal as well as a means to get closer to oneself to Allah SWT. ${ }^{1}$ Mujahadah was born from the Qadariyah wa Naqsabandiyah order in Indonesia. This tarekat is an amalgamation of two large tarekat, namely the Qadariyah order and the Naqsabandiyah order. ${ }^{2}$ As a school of sufism, the Qadariyah wa Naqsabandiyah tarekat has several teachings that are believed to be true, especially in terms of kufr. Some of the teachings that are the views of this tarekat are related to the order (method) to get closer to

\footnotetext{
${ }^{1}$ M. Ofik Taufikur Rohman Firdaus, "Tradisi Mujahadah Pembacaan Al Qur'an Sebagai Wirid Di Pondok Pesantren Kebon Jambu Al-Islamy Babakan Ciwaringin Cirebon," Diya Al-Afkar: Jurnal Studi alQuran Dan al-Hadis 4, no. 01 (1 Juni 2016): 150, https://doi.org/10.24235/diyaafkar.v4i01.888.

${ }^{2}$ Kharisudin Aqib, Inabah: Jalan Kembali Dari Narkoba, Stres Dan Kehampaan Jiwa (Surabaya: PT. Bina Ilmu, 2012), 33, http://digilib.uinsby.ac.id/id/eprint/28179.
}

Allah SWT. ${ }^{3}$ In this tarekat, tazkiyatun nafsi is a method to purify the soul so that it feels calmer, more peaceful and serene as well as a way to adorn the heart with good behavior and cleansing oneself from reprehensible traits. $^{4}$

According to Imam Al-Ghazali in the journal Samsul Arifin there are two ways to hold back lust. Namely, with the learning process so that lust can submit to reason and syari'at, namely by praying and fortifying oneself with knowledge and charity so that they can control their anger. ${ }^{5}$ According to him, self-habituation can also be done through riyadhah and mujahadah so that everyone can introspect themselves. ${ }^{6}$ In the Qadariyah wa Naqsabandiyah tarekat riyadlah an-nafsi is a process of forming and

\footnotetext{
${ }^{3}$ Aqib, 44.

${ }^{4}$ Aqib, 117.

${ }^{5}$ Samsul Arifin, "Konseling Berbasis Pesantren Untuk Memperkokoh Karakter Pelajar Dalam Menghadapi Globalisasi," LISAN AL-HAL: Jurnal Pengembangan Pemikiran Dan Kebudayaan 8, no. 1 (9 Juni 2014): 23.

${ }^{6}$ Apipudin Apipudin, "Peningkatan Kesehatan Mental Melalui Pembinaan Akhlak (Analisis Pemikiran Al-Ghazali," Studia Didaktika 10, no. 02 (2 Desember 2016): 99.
} 
dissolving the soul which is carried out consists of three levels, namely mujahadah continuously. Various forms as a means of ula, mujahadah saniah, and mujahadah mujahadah, one of which is fasting, wirid, both with hizib and al-Quran recitation as salisah (mujahadah majlis al-syahadah). ${ }^{9}$

Activities of dhikr and praying have well as prayer reading. ${ }^{7}$

Most mujahadah traditions are become a common tradition by muslims in applied to salafiyah Islamic boarding schools to train the riyadhah of the students, such as the mujahadah tradition at Islamic boarding schools Kebon Jambu Al-Islamy Babakan Ciwaringin Cirebon which contains the recitation of al-Quran as wirid. Wirid is a form of worship or routine that is usually done after the prayer is finished in which there are several verses of the Koran such as the reading of the thayyibah sentence (istighfar, hamdalah, tasbih) and in this Islamic boarding school the mujahadah is reciting one juz of the Koran. ${ }^{8}$ According to KH. Abdurrohman Khudhori each boarding school has a different way of running the mujahadah. Riyadhah is one of the ways that Islamic boarding schools do as a form of learning in addition to the applicable curriculum.

Unlike the mujahadah which was carried out at the al-Ittifaqiah Islamic Boarding School in Sumatra, it was an attempt to improve the memorization of the al-Quran memorizing santri. Mujahadah

\section{${ }^{7}$ Firdaus, "Tradisi Mujahadah Pembacaan Al Qur'an Sebagai Wirid Di Pondok Pesantren Kebon Jambu Al-Islamy Babakan Ciwaringin Cirebon," 151.} ${ }^{8}$ Firdaus, 151.

Indonesia. Until now, various dhikr assemblies have appeared in both large and small forums. Among them is the dhikr assembly in Yogyakarta, namely the Taklim al-Taqwa assembly. The activities carried out in the assembly included the implementation of the mujahadah and routine recitation every Thursday night. By holding these activities, it can provide spiritual education for the people who participate in these assemblies. ${ }^{10}$ Meanwhile, the mujahadah in PP al-Munawwir Krapyak contains the recitation of prayer and recitation of the verses of the Quran which are carried out in congregation. ${ }^{11}$

${ }^{9}$ Amin Muhammad, "Tradisi Mujahadah Taḥiz Al-Qur'ān Di Pondok Pesantren Al-Ittifaqiah Indralaya Ogan Ilir Sumatera Selatan (Analisis Living Qur'an)," Dirosat : Journal of Islamic Studies 2, no. 2 (27 Februari 2018): 123, https://doi.org/10.28944/diros at.v2i2.106.

${ }^{10}$ M. Al-Qodhi Abi Saidil Mahzumi dan A. Jauhar Fuad, "Spiritual Education Through Ziarah Tradition In Syaikh Syamsuddin Al-Wasil Town Kediri City," EL HARAKAH Jurnal Budaya Islam 21, no. 2 (3 Desember 2019): 237-54, https://doi.org/10.18860/el.v21i2.7030; Abdul Munip, "Model Public Speaking Kyai Dalam Menanamkan Nilai-Nilai Pendidikan Pada Jamaah Majelis Doa Dan Taklim At-Taqwa Wonokromo Pleret Bantul DIY," Cendekia: Jurnal Kependidikan Dan Kemasyarakatan 14, no. 1 (30 Juni 2016): 3, https://doi.org/10.21154/cendekia.v14i1.613.

${ }^{11}$ Moh. Muhtador, "Pemaknaan Ayat Al Qur'an dalam Mujahadah (Studi Living Qur'an di PP Al Munawwir Krapyak Komplek Al Kandiyas," Jurnal Penelitian 8, no. 1 (2014): 101. 
Research on the theme of mujahadah is very rare and even researchers have not yet found it applied to public schools, especially vocational high schools. Most of the mujahadah traditions are applied to pondok pesantren and majelis taklim. Seeing a little or even a school that applies the mujahadah tradition, so the researcher want to explore the value of religiosity in students in the mujahadah tradition at the Islamic Vocational School Ulul Albab Nganjuk.

The mujahadah activities carried out at the Ulul Albab Islamic Vocational School contain the activities of sunnah prayers and the recitation of prayers is a tradition that exists at Ulul Albab Islamic Vocational School. This tradition is carried out by all students of Islamic Vocational School Ulul Albab and led by the head of the foundation. And this vocational school also has a routine routine every day, namely the implementation of dhuha prayers in congregation every morning and followed by recitation of the al-Quran memorization. With the existence of the mujahadah routine at the Ulul Albab Nganjuk Islamic Vocational School, it is a differentiator from other schools.

\section{Research methods}

This research is a qualitative research, which is an approach used to process data without using numerical counts, but only using the presentation of thoughts, opinions of several experts, and also observations of phenomena that occur in society. This study uses a phenomenological approach which is a study used to explain, reveal the meaning of a concept or phenomenon or experience that occurs in several individuals. This approach is carried out in natural situations, so that there are no limitations in interpreting or understanding phenomena as a step to deepen the values of student religiosity in the mujahadah tradition at SMK Islam Ulul Albab Nganjuk. So the researchers used data collection procedures with in-depth interviews and participant observation methods where researchers participated in the mujahadah activities held at the Islamic Vocational School Ulul Albab Nganjuk.

\section{Result and Discussion}

\section{Mujahadah and Religious Values}

Mujahadah is a process of studying religious knowledge as well as a means of spreading Islamic dakwah which has a role in forming a noble and perfect personality. In accordance with the Quran and Sunnah, it is hoped that they will be able to control oneself, because based on the moral principles of a person, a person will be more stable in living life.

Mujahadah is also a form of seriousness to carry out Allah's orders by carrying out all obligations and staying away 
from all His prohibitions, both physically and mentally with a tangible form of behavior that seeks to fight (subdue) lust. Mujahadah can also be in the form of avoiding small sins (muru'ah), doing routine amaliyah-amaliyah such as Monday-Thursday fasts and other sunnah fasts, not leaving Rawatib sunnah prayers (qabliyah and ba'diyah) and sunnah prayers. other.

In his journal Afifudin explained that the concept of mujahadah, riyadlah, muhasabah and muraqabah which tend to be more practical-applicative, al-Ghazali prioritizes the achievement of the goal of forming real Islamic morals with a focus on the personality of the Prophet, as uswatun hasanah. ${ }^{12}$ Mujahadah can also mean an effort to fight lust, as well as an attempt to fight and combat bad character and behavior caused by his anger, which is commonly called mujahadah al-nafs in connection with this, Allah said, "And those who jihad to (seek pleasure) Us, We will truly show them

${ }^{12}$ Afifudin Afifudin, "Pendekatan Sufistik Dalam Sistem Pendidikan Islam Di Perguruan Tinggi Studi Fenomenologis Program Pencerahan Kalbu Di Pesantren Mahasiswa UMI Dar Al-Mukhlisin Labbakkang Pangkep," INFERENSI: Jurnal Penelitian Sosial Keagamaan 11, no. 1 (1 Juni 2017): $\nleftarrow$ 75-96, https://doi.org/10.18326/infsl3.v11i1.75-96; m Jauhar Fuad, "Pendidikan Karakter Dalam Pesantren

N Tasawuf," Jurnal Pemikiran Keislaman 23, no. 1 (28

our ways. and Allah truly is with those who do good. "13

Fathurahman in his book explains that hujjatul Islam Imam Ghazali in his Ihya' states that: "Mujahadah is the key (door) of guidance, there is no key to guidance other than mujahadah." In the mujahada there are recitation of dhikr, tahlil, prayer and wirid which contain verses from the Koran which can make the mood calm, and make behavior in everyday life better. ${ }^{14}$

Based on the studies above, it leads to a general picture that the mujahadah tradition is closely related to religiosity. That the existence of the mujahadaat can get closer to Allah's face to God.

Religiosity is basically always related to behavior or behavior. This behavior is closely related to the mindset, principles and rules that a person uses relating to good and bad behavior. The concept of religiosity according to Skinner is the same as staying away from the prohibitions established by religion. Jalaludin defines religiosity as a condition that exists in a person that triggers them to behave in accordance with the level of obedience to religious teachings.

According to Imron, in his writing, he says that religiosity is more inclined to the

\footnotetext{
13 “Al-'Ankabut - العنكبوت | Qur'an Kemenag," diakses $\quad 8 \quad$ September 2020, https://quran.kemenag.go.id/pagesura/29.

${ }^{14}$ Zainuri Ihsan, M. Fathurahman, Mujahadah (Bacaan dan Amalan Penting untuk Mempercepat Terkabulnya Hajat) (Tim Medpress, 2015), 25. 
aspect of conscience, namely the relationship between humans and their creators, and behaving according to the Creator's rules. Besides focusing more on the relationship to God, but still not forgetting the relationship with fellow humans. ${ }^{15}$

Dwiwiyati in her writing explains that in a book American Piety: The Nature of Religious Commitment written R. Stark and C.Y. Glock: religiosity (religiosity) includes five dimensions, namely:

1. The ritual dimension, namely the extent to which a person performs his obligations in religion.

2. The ideological dimension, namely the extent to which a person can accept the belief in his or her religion.

3. Intellectual dimension, namely the extent to which a person understands, understands and knows about the teachings of his religion, and the extent to which someone wants to learn and increase knowledge about the teachings of his religion. With mature knowledge about the teachings of the religion he adheres to, it will make a person have broad insights in thinking so that behavior in various ways is more focused.

${ }^{15} \mathrm{M}$. Imron Abadi, "Memahami Nilai Religiusitas dalam Kepemimpinan Ahok sebagai Bentuk Regulasi Diri," BELAJAR BAHASA: Jurnal Ilmiah Program Studi Pendidikan Bahasa dan Sastra Indonesia 1, no. 1 (26 Juli 2016): 92, https://doi.org/10.32528/bb.v1i1.76. Jurnal Intelektual: Jurnal Pendidikan dan StudiKeislaman Volume 10, Nomor 2, Agustus 2020
4. The experiential dimension, namely the extent to which a person can feel and experience feelings and get religious experience. In this dimension, there is a feeling of feeling close to Allah, a feeling of peace, being happy because of the deity of Allah and a feeling of solemnity when performing prayers.

5. Consequence dimension, namely the extent to which a person is willing to commit to the teachings of the religion he adheres to in everyday life. ${ }^{16}$

Meanwhile, there are two factors that influence religiosity, namely internal and external factors. There are several internal factors that can influence religiosity, including heredity, age, personality and psychological conditions. Meanwhile, the external factors that influence religiosity are family factors, institutional environment and community environment.

In adolescence this is a period of extension in the phase of children towards their maturity level. In this phase, their emotional condition is not stable and their social behavior still needs time to develop into the maturity phase. And in terms of thinking they are still developing towards

${ }^{16}$ Dwiwiyati Astogini, Wahyudin Wahyudin,
dan Siti Zulaikha Wulandari, "Aspek Religiusitas
Dalam Keputusan Pembelian Produk Halal (Studi
tentang labelisasi halal pada produk makanan dan
minuman kemasan)," Jurnal Ekonomi, Bisnis, dan
Akuntansi 13, no. 1 (13 Februari 2014): 2,
http://jp.feb.unsoed.ac.id/index.php/jeba/article/view/3
45.

${ }^{16}$ Dwiwiyati Astogini, Wahyudin Wahyudin, dan Siti Zulaikha Wulandari, "Aspek Religiusitas Dalam Keputusan Pembelian Produk Halal (Studi tentang labelisasi halal pada produk makanan dan minuman kemasan)," Jurnal Ekonomi, Bisnis, dan Akuntansi 13, no. 1 (13 Februari 2014): 2, http://jp.feb.unsoed.ac.id/index.php/jeba/article/view/3 
perfection. In this phase, religion plays the most important role in adolescent life. The development of children in adolescence is also based on their physical and spiritual development. His understanding of his religious teachings can be seen from the development within himself.

Some of the factors that indicate the religious spirit of adolescents has begun to develop, namely, the growth and development of their mind and mentality, feelings that begin to develop, they also begin to consider their social conditions, their morals have also begun to develop, their attitudes and interests in religion and their attitudes. in worship.

In this adolescence, their religious soul is still unstable, because psychologically, the mental condition of these teenagers has not yet reached maturity so that in terms of religion they still feel doubts that trigger conflict in their souls. Some of the factors that trigger adolescents to experience doubt include the following:

1. Misinterpretation of personality related to gender.

2. Wrong in joining a religious organization and also wrong in choosing role models in religious terms.

3. That humans are happy with new things, they are classified as curious

about teachings that are new and interesting to them.

4. Meanwhile, people who already believe in the tradition they adhere to, will not believe or doubt the newly arrived teachings.

5. Education, that the level of knowledge and education of a person will also affect his religious attitude.

6. Mixing of religion and mysticism. ${ }^{17}$

\section{Mujahadah Tradition and Religious} Values in Ulul Albab Nganjuk Islamic Vocational School

Tazkiyatun Nafsi or purifying the soul in tarekat means decorating the heart and soul with praiseworthy deeds and also as an effort to cleanse oneself from all despicable traits. Tazkiyat al nafsi can also mean an effort to condition the soul to always feel calm, serene and happy in terms of worship (getting closer to Allah). One of the methods of tazkiyatun nafs is the mujahadah. ${ }^{18}$

The mujahadah tradition is inseparable from an existing practice (such as dhikr and istigasah) and has been around for a long time and was carried out by our predecessors, such as masyayikh (kyai) or religious figures and warriors as a form of riyadhah, to train one's personal as well as a means. to get closer to Allah SWT. Various

\footnotetext{
${ }^{17}$ Noer Rohmah, Pengantar Psikologi Agama (Yogyakarta: Teras, 2013), 131-34.

${ }^{18}$ Aqib, Inabah, 117. 
forms of activities are carried out as a means of mujahadah, including by performing sunnah practices such as performing sunnah fasting, wirid, both by saying tayyibah and by reading the al-Quran including by reciting selawat. ${ }^{19}$

According to al-Ghazali there are two ways to hold back lust. Namely, with the learning process so that lust can submit to reason and syariat, namely by praying. Fortify oneself with knowledge and charity so that they can control their anger. According to him, self-habituation can also be done through riyadhah and mujahadah, one of which can be done by always advising yourself and also by increasing the number of dhikr to Allah SWT. ${ }^{20}$ Dhikr is the easiest and most efficient way to rid yourself of all diseases that are present in the heart. And this dhikr is a method often used in all tarekat, including the mujahadah.

Mujahadah can mean as an effort to fight lust, as well as an effort to fight all the bad qualities and actions caused by his anger. Mujahadah is also an effort to study science related to religion and also as a method of preaching in an islamic manner which plays an important role in building and training

\footnotetext{
${ }^{19}$ Firdaus, "Tradisi Mujahadah Pembacaan Al Qur'an Sebagai Wirid Di Pondok Pesantren Kebon Jambu Al-Islamy Babakan Ciwaringin Cirebon," 151.

${ }^{20}$ Arifin, "Konseling Berbasis Pesantren Untuk Memperkokoh Karakter Pelajar Dalam Menghadapi
} Globalisasi," 23. Jurnal Intelektual: Jurnal Pendidikan dan Studi Keislaman Volume 10, Nomor 2, Agustus 2020 one's personality to become a better person. ${ }^{21}$ The mujahadah tradition focuses more on religious experience as a spiritual fortress for someone who does it and also as an attempt to ask for the desires of God Almighty. Mujahadah is also a way of strengthening the spiritual soul as an effort to develop islamic scholarship in the world of spiritual education because it provides more individual strengthening in the affective aspect. $^{22}$

The mujahadah tradition carried out at SMK Islam Ulul Albab Nganjuk is a tradition carried out in order to commemorate the establishment of the Daru Ulil Albab Islamic Boarding School Foundation which contains a prayer activity with the whole family of the Daru Ulil Albab Islamic Boarding School, intended to make all YPP DUA residents feel one heart, feel they belong, and contribute to the process of growth and development of the foundation. Also in order for a process of spiritual education, spiritual maturation and personal success in life, for each person. ${ }^{23}$ This mujahadah tradition contains the recitation of Hizb al Quran and Ratib Hadad, then ${ }^{21}$ Arifin, 23.
${ }^{22}$ Muhammad Lutfianto Alfarisi, “Tipologi
pendidikan spiritual santri secara dhohiriyah dan
ruhaniyah di Pondok Pesantren Metal Moeslim Rejoso
Pasuruan" (undergraduate, Universitas Islam Negeri
Maulana Malik Ibrahim, 2016), http://etheses.uin-
malang.ac.id/5378/.
Februari 2019. $\overbrace{\substack{n \\ 0 \\ 0}}^{N}$ 
continued with sunnah prayers, reading ratib istigasah then tausiyah after that it is continued with dhuhur prayer in congregation and ends with mushafahah.

Meanwhile, the mujahadah in the Luqmaniyah Islamic boarding school in Yogyakarta is a mujahadah tradition which contains recitation of selawat, dhikir, mahalul qiyam, prayer and hasanah mauidhah. This mujahadah tradition is an attempt to train santri religiosity especially for the community. Through this mujahadah, the santri as well as the community get spiritual education without leaving the traditions of our predecessors, especially Wali Songo as successors to the Anbiya'. ${ }^{24}$

It is also not much different from the mujahadah which is carried out in the Thoriqul Huda Islamic boarding school which contains prayers, dhikr and prayers carried out in congregation with the aim of getting closer to Allah SWT. According to Kyai Fachruddin Dasuki mujahadah is a jihad against Allah, namely jihad with oneself (jihad nafs) to clean oneself by means of riyadhah. Mujahadah is a spiritual riyadhah which functions to improve the quality of faith in Allah and to shape personality.

Mujahadah is also a religious activity carried out by individuals and groups with the intention of taqarrub (closer to oneself) to Allah through various methods such as fasting, holding back lust, and also dhikr to Allah. Mujahadah is implemented as a medium for servant communication to God with dhikr and wirid, reading verses from the al-Quran, selawat and also reciting prayers.

Mujahadah which is held at Ulul Albab Islamic Vocational School is expected that all students can become even better individuals and so that their spiritual souls will increase, and also so that their spirituality will mature. With mujahadah hoped that they will have a good attitude of religiosity, their morals will change and they are also fond of dhikr, by holding mujahadah they are taught in practice about the procedures for dhikr so that they will later be practiced outside the school environment, or later after they leave here to practice taqarub ilallah, dhikr and pray. ${ }^{25}$

In the mujahadah there are many readings of the hizb al Quran, ratib al-hadad, as well as sunnah prayers, there is also a ratib istigasah in which there is a reading of yasin washilah which contains the prayers of munjiyat. With the implementation of this mujahadah, it is hoped that students will gain peace of mind and soul, and are also expected to become better individuals and become devout and salehah children. 
During adolescence there are several factors that trigger adolescent religiosity, including family and environmental factors. In addition to encouragement and education from the family, the surrounding environment is also very influential in determining their religious attitude, such as the students of Islamic Vocational School of Ulul Albab. Whereas in this SMK there is a tradition that can influence their religious attitudes or religiosity, namely the mujahadah tradition. $^{26}$

According to the interview the writer did, the visible impact on students after doing mujahadah was that after participating in mujahadah activities, on average, they felt calm in themselves, they felt that their spiritual soul increased after actively participating in mujahadah activities. Even though there are some of them who are still confused about how they feel after joining the mujahadah, many of them have already felt that there is a change in them. They feel calmer, more serene and peaceful. There is also one student who initially rarely prayed at home while actively participating in the mujahadah, he became more diligent in praying 5 times a day. However, the change in their dhahir or what appears to them is still not visible.

\footnotetext{
${ }^{26}$ Kharisudin Aqib, Tausiyah
} dalam
It can be seen that the implementation of the mujahadah and also the goals to be achieved for these students is still not maximized, perhaps also because the implementation of the mujahadah is only done once a month, therefore the effect or impact on increasing the religious value of students is still not felt. maximum by students.

The development of children in adolescence is also motivated by physical and spiritual development. The understanding of children in adolescence towards religious teachings can be seen in their own development. In this phase, the condition of their religious spirit tends to be unstable, this problem is caused because psychologically these teenagers have not reached maturity so that in understanding their religion they feel doubts that trigger conflict in their souls. With the psychological condition of adolescents described above, it is very appropriate for students to be guided and directed through this mujahadah activity.

\section{Conclusion}

The mujahadah tradition is an effort made to fight lust, as well as to combat all despicable attitudes and behaviors caused by his anger. Mujahadah is also an effort to study science related to religion and also as a method of preaching in an islamic manner which plays an important role in building and 
training one's personality to become a better person. Meanwhile, the mujahadah tradition at Ulul Albab Islamic Vocational School contains the recitation of Hizb al Quran and Ratib Hadad, then continued with sunnah prayers, reading ratib istigasah then tausiah after that it is continued with dhuhur prayer in congregation and ends with mushafahah.

Mujahadah, which is held at Ulul Albab Islamic Vocational School, is intended so that all students can become even better individuals and so that their spiritual souls can increase, and also so that their spirituality becomes more mature. The results of observations on the implementation of the mujahadah at Ulul Albab Islamic Vocational School show that students' awareness of the importance of the mujahadah is still lacking, but in its implementation they are very enthusiastic and happy in doing it. After actively participating in the mujahadah they (students) feel calm within themselves, and they also feel that their spiritual soul increases after actively participating in mujahadah activities. Although the changes seen are still not optimal.

\section{Bibliography}

Abadi, M. Imron. 'Memahami Nilai Religiusitas dalam Kepemimpinan Ahok sebagai Bentuk Regulasi Diri." BELAJAR BAHASA: Jurnal Ilmiah Program Studi Pendidikan Bahasa dan Sastra Indonesia 1, no. 1 (26 Juli 2016). https://doi.org/10.32528/bb.v1i1.76.
Afifudin, Afifudin. "Pendekatan Sufistik Dalam Sistem Pendidikan Islam Di Perguruan Tinggi Studi Fenomenologis Program Pencerahan Kalbu Di Pesantren Mahasiswa UMI Dar Al-Mukhlisin Labbakkang Pangkep." INFERENSI: Jurnal Penelitian Sosial Keagamaan 11, no. 1 (1 Juni 2017): 75-96. https://doi.org/10.18326/infs13.v11i1. 75-96.

“Al-'Ankabut - العنكبوت | Qur'an Kemenag." Diakses 8 September 2020. https://quran.kemenag.go.id/pagesura/ 29.

Alfarisi, Muhammad Lutfianto. "Tipologi pendidikan spiritual santri secara dhohiriyah dan ruhaniyah di Pondok Pesantren Metal Moeslim Rejoso Pasuruan." Undergraduate, Universitas Islam Negeri Maulana Malik Ibrahim, 2016. http://etheses.uin- malang.ac.id/5378/.

Apipudin, Apipudin. 'Peningkatan Kesehatan Mental Melalui Pembinaan Akhlak (Analisis Pemikiran AlGhazali." Studia Didaktika 10, no. 02 (2 Desember 2016): 92-103.

Aqib, Kharisudin. Inabah: Jalan Kembali Dari Narkoba, Stres Dan Kehampaan Jiwa. Surabaya: PT. Bina Ilmu, 2012. http:/digilib.uinsby.ac.id/id/eprint/28 179.

Arifin, Samsul. 'Konseling Berbasis Pesantren Untuk Memperkokoh Karakter Pelajar Dalam Menghadapi Globalisasi." LISAN AL-HAL: Jurnal Pengembangan Pemikiran Dan Kebudayaan 8, no. 1 (9 Juni 2014): 19-34.

Astogini, Dwiwiyati, Wahyudin Wahyudin, dan Siti Zulaikha Wulandari. "Aspek Religiusitas Dalam Keputusan Pembelian Produk Halal (Studi 
tentang labelisasi halal pada produk makanan dan minuman kemasan)." Jurnal Ekonomi, Bisnis, dan Akuntansi 13, no. 1 (13 Februari 2014).

http://jp.feb.unsoed.ac.id/index.php/je ba/article/view/345.

Firdaus, M. Ofik Taufikur Rohman. 'Tradisi Mujahadah Pembacaan Al Qur'an Sebagai Wirid Di Pondok Pesantren Kebon Jambu Al-Islamy Babakan Ciwaringin Cirebon." Diya Al-Afkar: Jurnal Studi al-Quran Dan al-Hadis 4, no. $01 \quad$ (1 Juni 2016). https://doi.org/10.24235/diyaafkar.v4i 01.888 .

Fuad, Jauhar. "Pendidikan Karakter Dalam Pesantren Tasawuf." Jurnal Pemikiran Keislaman 23, no. 1 (28 Februari 2013). http://ejournal.iaitribakti.ac.id/index.php/tribakti/article /view/13.

Mahzumi, M. Al-Qodhi Abi Saidil, dan A. Jauhar Fuad. "Spiritual Education Through Ziarah Tradition In Syaikh Syamsuddin Al-Wasil Town Kediri City." EL HARAKAH Jurnal Budaya Islam 21, no. 2 (3 Desember 2019): 237-54.

https://doi.org/10.18860/el.v21i2.703

0 .

Muhammad, Amin. "Tradisi Mujāhadah Tahfiz Al-Qur'ān Di Pondok Pesantren Al-Ittifaqiah Indralaya Ogan Ilir Sumatera Selatan (Analisis Living Qur'an)." Dirosat: Journal of Islamic Studies 2, no. 2 (27 Februari 2018): 123-148-148. https://doi.org/10.28944/dirosat.v2i2. 106.

Muhtador, Moh. 'Pemaknaan Ayat Al Qur'an dalam Mujahadah (Studi Living Qur'an di PP Al Munawwir Krapyak Komplek Al Kandiyas.”
Jurnal Penelitian 8, no. 1 (2014): 93112.

Munip, Abdul. "Model Public Speaking Kyai Dalam Menanamkan Nilai-Nilai Pendidikan Pada Jamaah Majelis Doa Dan Taklim At-Taqwa Wonokromo Pleret Bantul DIY." Cendekia: Jurnal Kependidikan Dan Kemasyarakatan 14, no. 1 (30 Juni 2016): 1-18. https://doi.org/10.21154/cendekia.v14 i1.613.

Rohmah, Noer. Pengantar Psikologi Agama. Yogyakarta: Teras, 2013.

Zainuri Ihsan, M. Fathurahman. Mujahadah (Bacaan dan Amalan Penting untuk Mempercepat Terkabulnya Hajat). Tim Medpress, 2015. 